\title{
Volcanic Risk Mitigation that Could Have Been Derailed but Wasn't: Pinatubo, Philippines 1991
}

\author{
Chris Newhall * \\ Mirisbiris Garden and Nature Center, Sto Domingo Albay, Philippines
}

This is the story of a successful risk mitigation effort at Mount Pinatubo in 1991 that could easily have failed. The counterfactuals are the myriad of ways that the effort could have failed but didn't. Forecasts for a large, VEI 6 eruption were the basis of 10, 20, 30 and, during the climactic eruption, even $40 \mathrm{~km}$ radius evacuations. Let's use the metaphor of a train headed for the destination of successful mitigation, but that could have easily have been derailed or slowed and shunted off to a siding. Among the possible nodes of derailment: capability and trust between responding institutions; external distractions, both natural and man-made; early alert; scientific judgment of whether, when, and how big an eruption will occur; stochastic or unpredictable factors that can make even the best

OPEN ACCESS

Edited by:

Gordon Woo,

Risk Management Solutions,

United Kingdom

Reviewed by:

Christopher Kilburn,

University College London,

United Kingdom

Gill Jolly,

GNS Science, New Zealand

*Correspondence:

Chris Newhall

cgnewhall@gmail.com

Specialty section:

This article was submitted to

Geohazards and Georisks,

a section of the journal

Frontiers in Earth Science

Received: 18 July 2021 Accepted: 27 October 2021 Published: 17 November 2021

Citation:

Newhall C (2021) Volcanic Risk Mitigation that Could Have Been Derailed but Wasn't: Pinatubo,

Philippines 1991.

Front. Earth Sci. 9:743477. doi: $10.3389 /$ feart.2021.743477 scientific judgment moot; optimal balance between caution and decisive actions, by scientists and civil defense alike; and effective communication between all parties. Potential derailments are detailed at each of these nodes for Pinatubo.

Keywords: mitigation, Pinatubo, eruption forecasting, trust, communication, counterfactual, volcano risk

\section{INTRODUCTION}

Mount Pinatubo (hereafter, Pinatubo), in the Philippines, produced a large, VEI 6 eruption on June 15,1991 - now known to be the 3rd largest eruption in the 20th century - smaller than Santa Maria 1902, about half the size of Katmai 1912, and one-third the size of the famous Krakatau eruption of 1883. Twenty-thousand indigenous Aetas lived on and near Pinatubo, and nearly 1 million lowland Filipinos and two large American military bases were severely affected. About 400 were killed in the eruption, while many thousands were saved by eruption forecasts and evacuations.

Some counterfactuals about natural hazards note events that might have been much bigger or much smaller than what actually occurred. Indeed, based on what we learned from the geologic record AFTER June 15, the climactic eruption could have been an order of magnitude larger or several of orders of magnitude smaller. Magnitude of natural events is a major uncertainty in hazard and risk estimation.

Rather than focus on a larger or smaller eruption, this paper focuses on a different question: How might the mitigation effort have failed? Our focus is on the mitigation effort, not on the natural event. This paper documents a number of different factors that could have derailed or slowed mitigation efforts related to the main eruption, on June 15, 1991. Interested readers can find additional details of pre-eruption events in Newhall and Punongbayan (1996a) and in Leone and Gaillard (1999).

Newhall and Punongbayan (1996b) addressed the same theme as the current paper, but was written with shorter retrospect. Have the intervening years changed my earlier view of a "narrow margin of successful volcanic-risk mitigation?" No, quite the opposite. Narrow misses still occur. Reflections on Pinatubo and application of its lessons to other volcanoes have for me, reinforced the 


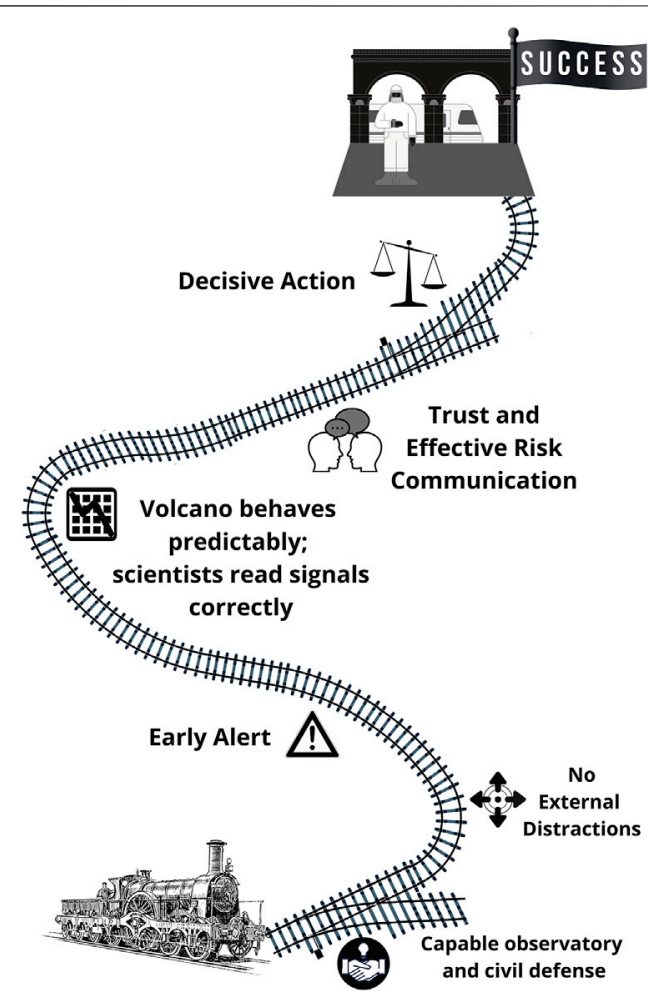

FIGURE 1 | Metaphorical path of train to successful risk mitigation, without getting derailed or shunted to siding along the way. Details of the various waystations in the Pinatubo case are given in the text.

importance (and fragility!) of human factors-including teamwork, trust, and attention to two-way communication. I am glad to see social scientists and professional communicators joining "physical volcanologists" in crisis responses.

A reviewer's comment bears special note: "Imagining how an outcome may have changed if certain people had behaved differently or (non-volcanic) events had taken a different course may at first sight appear to be an indulgence with limited practical application." This is true, so I invite readers to generalize from the specific individuals and past events of Pinatubo to individuals and processes of your own teams. Individuals and their past experiences will change, but lessons learned from one crisis should also add to the cumulative body of experience for the next. Post-facto analyses of crisis response, and papers like this, can help. Newhall et al. (2021) includes lessons from Pinatubo for successful volcanic risk mitigation elsewhere.

\section{AN ANALOGY WITH TRAIN TRACKS WITH DESTINATION OF SUCCESSFUL RISK MITIGATION}

Figure 1 shows metaphorical train tracks with a number of nodes along the route at which a mitigation "train" could get derailed or shunted onto a siding and slowed. Each node is described below in details particular to Pinatubo, but readers might well imagine this as a generic train of other risk mitigation efforts they have known. A few of these factors were unique to Pinatubo; most were not.

\section{Capable Observatory and Civil Defense}

Notwithstanding Hollywood portrayals of individual heroes who save the world, risk mitigation is generally a multi-institution and team effort. What institutions responded to Pinatubo? The first was the Philippine Institute of Volcanology and Seismology (PHIVOLCS), led by the late Dr. Raymundo Punongbayan. In 1991, PHIVOLCS was a relatively small agency which had, in the preceding decade, grown in capability and stature by responses to the eruption of Mayon Volcano in 1984 and to the M 7.8 Luzon earthquake of July 16, 1990. PHIVOLCS scientists had studied or were studying at universities in Manila and overseas, in the US, Japan, France, and New Zealand. Without direct crisis response responsibility, but with helpful geologic, geochemical, and drilling experience at Pinatubo, was the geothermal group of the Philippine National Oil Corporation (PNOC). Francisco "Jun" Delfin of PNOC provided valuable insights from PNOC's geothermal exploration of Pinatubo in the mid-late 1980s. The US Geological Survey had a USAID-USGS funded Volcano Disaster Assistance Program (VDAP), envisioned after the eruption of Mount St. Helens in 1980, beta-tested with PHIVOLCS at Mayon in 1984, and strengthened after the Nevado del Ruiz disaster in 1985, well-equipped and ready to help upon request. The author was on a several-year bureaucratic assignment in USGS headquarters, but had prior ties with PHIVOLCS and VDAP. A high level of trust had already been built between PHIVOLCS and the VDAP group. Similarly, for civil defense matters, PHIVOLCS already a long-standing and strong collaboration and trust with the National Disaster Coordinating Committee (NDCC) and its operating arm, the Office of Civil Defense, led by Engineer Fortunato Dejoras. So, in the general picture, institutional capability and trust were quite good.

But it is easy to imagine that it might not have been as good. Eruptions of Mount St. Helens in 1980, Mayon in 1984, and Nevado del Ruiz in 1985 might never have happened, so advances after those and many other eruptions might not have occurred. Every eruption teaches new lessons, and there is no singular path toward critical new understanding, but the abovementioned three eruptions were high in our consciousness. The influx of capable young scientists into PHIVOLCS was certainly promoted by the 1984 Mayon eruption and the 1990 M7.8 Luzon earthquake. Likewise, the USGS and USAID would not have formed and funded VDAP without Mount St. Helens and Nevado del Ruiz; Dr. Norman Banks of USGS deserves credit for being an early and tireless advocate of VDAP. Mayon. Trust between VDAP and PHIVOLCS was surely aided by Dr. Punongbayan having done his $\mathrm{PhD}$ studies in Colorado, personal friendship with several USGS scientists, the author's prior studies and family ties in the Philippines, and many a friendly discussion over beer.

At Pinatubo, Philippine and American militaries and USAID Philippines provided key logistical support. Neither PHIVOLCS nor USGS had much cash to commit to Pinatubo response, but logistics are expensive. We were concerned at first that our 
scientific response might become a political pawn in contentious negotiations for renewal of leases for the American military bases, but those who provided logistical help did so with almost no hint of politicization. Without the vehicles and drivers from USAID, and without the helicopter, housing, communications, and other support from US military, particularly the US Air Force at Clark Air Base before the eruption and US Navy and Marines at Subic Bay Naval Station after the eruption, and the Philippine Air Force both before and after the eruption, our scientific response would have been much slower and less effective. Where no roads were available, helicopters enabled us to reach sites and install instruments in hours, vs. days if on foot. When our team on the eastern side of Pinatubo ran out of cash (early on), being on Clark $\mathrm{AB}$ let us write IOUs and charge credit cards. When we needed closer looks from the air, helicopter and satellite support helped immensely.

The strength of these institutions and mutual trust was the engine that powered the train toward mitigation.

A sub header under institutional capability is the experience of team members, and, more explicitly, eruptions they have known. All volcanologists are strongly influenced by eruptions they have known, and also by what has been learned by colleagues at other volcanoes. Collectively, the team members at Pinatubo had a wide range of experience. One could list dozens, probably hundreds of scientific and response-related lessons that build the collective experience and knowledge of any team, and the counterfactual here is that one can also imagine dozens of those lessons that would NOT have been learned, or available to the Pinatubo team, had those earlier eruptions not occurred, or had the team members not been involved in those earlier eruptions or learned about them from scientific meetings and literature. Several of the key PHIVOLCS team members had valuable experience from Mayon; I had learned much about large silicic eruptions and deposits from Mount St. Helens and earlier work at Atitlán caldera, and Director Punongbayan had also visited Mount St. Helens. On the response side, the then-still-fresh eruption of Redoubt Volcano in 1989-90 had pushed me and other reluctant scientists to simplify our message into simple alert levels, drawing at that time from an earlier scheme suggested by the late John Tomblin for Rabaul Caldera in the early 1980's. And our collective experience with the giant landslide and lateral blast at Mount St. Helens, though not likely at Pinatubo, was a constant reminder that "worst cases" really do occur, and must be foretold!

\section{External Distractions, Both Natural and Man-Made}

No volcanic crisis arises in a vacuum, and other events can be distractions. From Nature, the M7.8 Luzon earthquake of 1990 had commanded most of PHIVOLCS' attention during the preceding year, and (earthquake-triggered) unrest at Taal Volcano, close to Manila, was demanding most of its time and resources up until, and even for a short time after, the first unmistakable signs of unrest at Pinatubo on April 2, 1991. It is easy to imagine that if Taal had erupted in early 1991 as it did in early 2020, or worse, PHIVOLCS would have been so preoccupied with Taal that Pinatubo would not have gotten the attention that it needed. Volcano observatories have limits to their logistical and staffing capabilities, and workloads need to be managed to avoid burn-out.

Potential man-made distractions included the contentious renegotiation between the US and the Philippines for Clark Air Base and Subic Bay Naval Station; focus by the author on organization of the first International Workshop of Volcanic Ash and Aviation Safety scheduled for July 1991; and focus by USAID Office of Foreign Disaster Assistance (OFDA) on post-Gulf War recovery in Kuwait. The first was a political minefield that both PHIVOLCS and the USGS wanted to avoid. Science and natural disasters are apolitical, and our responses should be too.

Another distraction was concern from USAID that USGS was using Pinatubo as an excuse for research under USAID funding. Initially, neither the USAID Mission Director in the Philippines nor OFDA in Washington supported the idea of VDAP help at Pinatubo, and USGS could not respond without USAID approval and support. It took phone calls and cables from the US Ambassador (Nicholas Platt), and 2 weeks, to get approval from USAID.

Another potential distraction was the ongoing New People's Army (NPA) guerrilla movement. The NPA controlled the upper slopes of Pinatubo and was generally suspicious of both the Philippine or American governments. Since we had to do geological reconnaissance and install remote instrument stations on Pinatubo, using logistics from USAID and the Philippine and American militaries, we were concerned that our humanitarian purposes might be misunderstood and that our fieldwork might be blocked and radios taken for other purposes. Personal safety was also a concern. Appropriate contacts with the NPA explained who we were, what was happening, and why our work should proceed.

External distractions might well occur in any volcanic crisis. For example, in the runup to the eruption of Nevado del Ruiz, a bombing at the Supreme Court of Colombia was a major distraction for the national government. Eruption responses in 2020-2021 are all influenced by the COVID pandemic, and although technology is helping to backfill for in-person collaboration, no inanimate tool or AI can substitute for the personal relationships and trust that is required between scientists and decision-makers.

\section{Early Alert}

Every eruption after a repose of centuries will have recognizable precursors of indeterminate duration. Scientists will know that the fuse has been lit, but won't know how long the fuse is. Time is of the essence. An early alert will help scientists to ramp up their monitoring and outreach activities. At well monitored volcanoes, the early alert will come from either ground-based or space-based instruments. At Pinatubo, there was no prior instrumental monitoring, but a small group of Aetas and missionary Catholic sisters living on the NW flank of Pinatubo noticed the small phreatic eruptions on April 2 and promptly went to Manila to report them to PHIVOLCS. What if they had not traveled promptly to Manila? That early alert gave extra days, perhaps even extra weeks of time for further preparations. In the final days of ramp-up to eruption, we were still desperately trying 
to convince officials, both American and Philippine, that it was time to move, and those extra days or weeks at the start were surely important at the end.

In the Philippines, local government officials (mainly, Mayors and Provincial Governors) have the main decision making authority for mitigation measures, sometimes acting on recommendations from national agencies. That system was already in place and functioning from the start of the Pinatubo crisis. The national Office of Civil Defense (Engr. Dejoras) organized a series of briefings for Governors and Mayors of the provinces surrounding Pinatubo, at which Dr. Punongbayan of PHIVOLCS laid out the hazards and started discussion of the potential need for evacuations. These briefings took place in May, early enough that the local government officials could make reasonable preparations.

Early in any episode of unrest, uncertainty will be high about the cause and about whether an eruption might follow. Most volcano observatories will err on the side of caution and respond immediately. If early unrest turns out to be a false alarm, little is lost, but if a response turns out to be too little or too late, much can be lost. The skepticism that we encountered at Pinatubo was both surprising and challenging but, in retrospect, understandable at any volcano that has not erupted in recent decades. Extra days of preparation, enabled by early alert, will be especially critical at long-dormant volcanoes.

\section{Scientific Judgment of Whether, When, and How Big an Eruption Will Occur}

Forecasting of eruptions is rarely simple. Volcanoes are complex systems with many processes, and volcanologists can observe only the surficial symptoms of unrest, not the actual subvolcanic processes themselves. We can study products of past eruptions to infer subvolcanic processes of previous eruptions at that volcano, but there is no guarantee that the same will be repeated. Interpretation of current seismic, geodetic, gas chemical, and other precursors starts with recognition of similar patterns from past eruptions, perhaps even globally, and then on qualitative or occasionally, quantitative interpretation of those precursors. In the case of Pinatubo, we knew that the volcano had not erupted for hundreds of years, so magma in the conduit had likely solidified. There was seismicity, at first $5 \mathrm{~km} \mathrm{NW}$ of the summit and later, beneath the summit, but we had almost no deformation data (this was before the era of GPS and InSAR). A ten-fold increase in $\mathrm{SO}_{2}$ emission, from $500 \mathrm{t} / \mathrm{d}$ to $5,000 \mathrm{t} / \mathrm{d}$ from mid to late May suggested that magma was involved and rising; then, a dramatic decrease in $\mathrm{SO}_{2}$ emissions occurred in earliest June (Daag et al., 1996).

There were, at the time, no guidelines about what precursors to expect for a VEI 6 eruption. No VEI 6 eruption had occurred anywhere in the world in the era of modern volcano monitoring. All we had was information about the range of precursor activity at moderately large VEI 4 and 5 eruptions, including some like Mount St Helens that were only marginally relevant. When one scales up to a VEI 6, does one simply look for the same, but stronger? In truth, no one knew.
Lessons learned partly at Pinatubo and partly elsewhere point out three potential misinterpretations of monitoring data. First, the earliest reports of earthquakes at Pinatubo, in August 1990 from the same Catholic nuns, were practically forgotten in attention to other aspects of the M7.8 event. After all, the whole central Luzon region had been shaken and stressed by the M7.8 earthquake. When seismicity began again in March 1991 and was determined in early April to be $5 \mathrm{~km} \mathrm{NW}$ of the summit along a known tectonic fault, it might have been interpreted as being of tectonic origin had it not been for phreatic explosions that occurred just NE of the summit. We know now of many cases, globally, of volcano-tectonic (VT) earthquakes that occur along tectonic faults up to several tens of kilometers away from volcanoes, but are now traceable to local pressurization caused by magma intrusion and/or pressurization of a hydrothermal system beneath a volcano. Pressurization of any confined aquifer along a regional fault will be particularly effective at triggering such "distal VT" earthquakes (White and McCausland, 2016; Coulon et al., 2017; McCausland et al., 2019). Ray Punongbayan deserves credit for thinking of a possible volcanic association even though the early April 1991 earthquakes were not directly beneath Pinatubo. We have known other instances in which distal VT swarms were dismissed by local scientists, in the Philippines and elsewhere, as being of purely tectonic origin and thus not of volcanological interest. Sometimes, these events are indeed mainly tectonic with secondary volcanic effects, but often, they reflect magmatic intrusion that triggers slip on nearby tectonic faults. At Pinatubo, early acceptance of a possible volcanic association gave added lead time for preparations, and an early call to VDAP rather than to those who work more in tectonic seismology.

A second possible misinterpretation could have occurred with respect to the sudden decrease in $\mathrm{SO}_{2}$ emission between May 28 and June 5, 1991. Stemming in part back to a volcanic crisis at Soufrière Guadeloupe in 1976, $\mathrm{SO}_{2}$ emission or lack thereof has been a point of considerable debate. At Mount St. Helens, very low $\mathrm{SO}_{2}$ emission before May 18, 1980 was interpreted on April 6 by well-known volcanologist Haroun Tazieff, one of the Soufrière Guadeloupe protagonists, as indicating that Mount St Helens would not produce a serious eruption. We had interpreted the increase at Pinatubo through late May as indicating magma ascent, so did the sudden decrease mean that magma had stalled? We were puzzled but interpreted it as a temporary aberration, perhaps from quenching and sealing of the carapace of rising magma. Today, we know that might also have been from scrubbing of $\mathrm{SO}_{2}$ into groundwater, or mechanical sealing of fracture permeability, or any combination of the three, so that a sudden decrease in $\mathrm{SO}_{2}$ emission is actually a warning sign, not a reason to relax (Stix et al., 1993; Fischer et al., 1994; Symonds et al., 2001). This lesson has been reiterated and reinforced elsewhere since 1991, so it is unlikely to be forgotten or misinterpreted in the future. But the generic lesson is this: There may well be other unrest in future crises that is puzzling and easily misinterpreted. The fact that volcanologists still debate the causes of unrest at other volcanoes, e.g., the role of shallow magma intrusions at Campi Flegrei 
(Gottsmann et al., 2006; Aiuppa et al., 2013; Chiodini et al., 2016; Troise et al., 2019), is a reminder that unrest can still be misinterpreted.

A third possible misinterpretation involved geologic data. Forecasting the size of an impending eruption is even more difficult than the date or time of onset. At Pinatubo, geologic reconnaissance suggested that all previous eruptions were of VEI 6 or larger. Admittedly, we could have missed deposits from smaller eruptions. Had only a small eruption occurred, societal disruption would have been judged unnecessary and scientists would have been severely criticized.

Or, more ominously, our "worst case" scenario could have been too small, and evacuations could have been insufficient. We thought a VEI 6 was Pinatubo's "worst-case scenario," and showed that in a hastily prepared hazard map (Punongbayan et al., 1996). Rick Hoblitt of the USGS suggested a possible underestimate based on field work just before the eruption in the Abacan River just outside Clark AB, but it was not until field work after the eruption that we confirmed the underestimate. The Inararo eruption of $\sim 81 \mathrm{ka}$ left $\sim 25 \mathrm{~km}^{3}$ (bulk volume) of deposits, and even the Crow Valley eruption of $\sim 5 \mathrm{ka}$ left $\sim 10-15 \mathrm{~km}^{3}$ of deposit, several times more voluminous than 1991 (Newhall et al., 1996). What we underestimated was the degree to which, after a huge eruption, fresh deposition on alluvial fans will cover and hide the distal reaches of pyroclastic flows.

Were there any other geologic data that could have helped us to forecast the size of eruption? Volcanologists have long known of an association between repose time and size of an eruption that follows. With the benefit of hindsight, we now understand that the 1991 eruption of Pinatubo was as large as it was because of accumulation of "excess" volatiles in discrete bubbles even while the magma was in storage, 6-11 km deep (Gerlach et al., 1996; Mori et al., 1996). The descriptor "excess" refers to volatiles from unerupted magma, above and beyond volatiles that saturate the erupted melt. Volatiles are supplied over time along with mafic magma, and when these were not erupted the volatiles accumulated in the upper part of Pinatubo's dacite magma reservoir, well in excess of saturation, hence as discrete volatile bubbles. The ready availability of this discrete volatile phase, without any further time required to diffuse through melt, is a critical enabling factor for plinian eruptions. It appears that the 500-600 years since the Buag eruption was enough to supply excess volatiles to residual dacite melt beneath Pinatubo. Before the eruption, all we could say was that the latest repose was in the same order of magnitude as previous reposes, as gleaned from hastily collected and analyzed charcoal samples. It was plausible but certainly not proven that Pinatubo would produce another large eruption. Today, with the story of volatile accumulation better understood, we can understand that the 1991 eruption (low-end VEI 6) was among the smaller eruptions of Pinatubo because the $\sim 600$ years repose was among the shortest known reposes-possibly because the 1990 earthquake triggered the eruption before it would have normally occurred. Since the 1991 eruption was at the low end of what might have occurred, our hazard maps turned out to be "just right." Everything is clearer in hindsight than in the height of a crisis.

What if a larger "worst-case" Inararo or Crow Valley eruption had occurred? The lethal footprints of those eruptions were larger than we realized before the 1991 eruption. As many as several hundred thousand might have been killed. Global effects on climate would have been worse than those of Katmai or Krakatau, but less severe than those from Tambora (1815 CE) or Rinjani (1256 CE).

All of these lessons on forecasting eruptions, and many more, are now being integrated with physics-based models to improve forecasts even more (e.g., Kilburn, 2018; Poland and Anderson, 2020).

\section{Stochastic or Unpredictable Factors That can Make Even the Best Scientific Judgment Moot}

In any episode of magma ascent, there are various forces promoting and inhibiting ascent. A vigorous supply of magma from depth, high volatile contents, low viscosity and low density all promote ascent. Weak magma supply, degassing and associated increases in viscosity, impenetrable strata or density barriers, and tectonic clamping of faults inhibit magma ascent. Almost none of these are directly observable, yet any one or several can spell the difference between magma erupting vs. stalling as an intrusion. In popular jargon, these are tipping points. The balances between promotion and inhibition of magma ascent are delicate, and quite small changes can radically change the outcome. Since the small changes cannot be observed, there is an element of chance (toss of the dice) as to whether magma will erupt. Volcanologists have some ideas about how to tell the difference-e.g., rapid magma ascent and accelerating unrest favoring eruption-but there are cases where unrest simply stops, surprising both scientists and officials (e.g., Geshi et al., 2010; Poland, 2010; Moran et al., 2011).

Based on the fact that seismicity fluctuated but did not start systematic acceleration until early June, the magma rising at Pinatubo could have stalled without eruption anytime up until the end of May (Harlow et al., 1996). Or, if pauses in the ascent were frequent and long enough, the magma could have degassed to the point that only effusive dome growth would occur, without any explosive follow-up. Indeed, the first magma that reached the surface on June 7 did exactly that-forming a dome visible only to those in helicopters-so volcanologists' credibility was briefly challenged. Over the next few days, though, it became evident that only the vanguard magma was degassed, and that explosive eruptions would follow.

Another stochastic element also came into play in the final days before June 15: Typhoon Yunya (local name, Diding). While the typhoon itself was forecast a few days in advance by the Philippine weather bureau PAGASA, it posed exceptionally difficult challenges in mitigation. Scientists anticipated that ash loading would be exacerbated because wet ash weighs much more than dry. The solution would be to shovel or wash ash off roofs as quickly as it fell. But the last place that anyone wants to be during the combination of typhoon, heavy ashfall, and lightning, is on a 
roof, shoveling wet ash. Large buildings were natural places of refuge, but their large roof spans also increased the risk of roof collapse. Warnings were given but lost in the noise. Sadly, most of the $\sim 400$ fatalities during the eruption were from collapse of wetash-laden roofs where people had taken shelter.

\section{Optimal Balance Between Caution and Decisive Actions, by Scientists and Civil Defense Alike}

Scientists are trained to be cautious in their interpretations, and to gather more data until a compelling story emerges. We must satisfy rigorous reviews to publish scientific papers. We demand of ourselves and others a high level of certainty, and that any remaining uncertainty be revealed and preferably quantified. No scientist should ever publish numerical values without including the " \pm ," typically 1 or 2 sigma standard deviation. A scientist who makes interpretations without enough data risks unshakeable scorn from the scientific community; a reputation as a "quick draw" or "loose cannon" will be difficult to overcome. Those who "cry wolf" too often will lose credibility.

At the same time, volcanic crises demand answers even before all of the data can be collected. A civil defense official or politician will need to make mitigation decisions, and will demand answers from scientists, often before the latter are comfortable making an interpretation. It is a clash of cultures. Scientists who respond to volcanic crises know the dilemma well, and do their best to balance caution vs. giving timely advice. We understand that officials need our advice, but we also need officials to understand that our advice comes with considerable uncertainty.

At Pinatubo, PHIVOLCS and USGS scientists in the field were struggling to understand and forecast activity. Scientists in the field were talking daily, sometimes even hourly, with Dr. Ray Punongbayan, Director of PHIVOLCS. Ray was responsible for nearly all public statements to officials and to the news media, and was also contributing to the science, particularly by air photo interpretation. He understood that the possible events were of such large size that there was no sense trying to fine-tune our advice. Advice needed to be simple and cover what we thought was the worst-case scenario. Ray also understood, better than most of the rest of us, that in the Philippine culture, scientists are expected to know the answer, not to still be searching for it, so it was better for his and our credibility for him to gloss over the uncertainties. He painted a clear, relatively simple picture, with bulls-eye radius-determined evacuation zones that ignored topography, and a jointly-developed alert level scheme that forecast the start of eruption to within the nearest 2 weeks and then $24 \mathrm{~h}$. He succeeded well in this regard, and events later proved his simplifications largely correct. There were moments when those of us in the field thought, whoa, we don't know that! And when Ray declared the highest alert level on June 9 some of us thought it was premature. But it was not premature for long, and it gave officials and residents several extra days to evacuate.

What if Ray had played the cautious scientist? Given events that transpired, he would have been late on his warnings. And if the volcano had not erupted? Well, it would have been a false alarm, and he could have lost his job. A Philippine weather forecaster lost his job for a lesser error. Ray knew the consequences, and took the personal risk to save others. I might not have lost my job, but I would have earned black marks for risking and "losing" so much of our volcano program's discretionary budget over a non-eruption. Increasingly, since the L'Aquila earthquake of 2009 in Italy, volcanologists and other natural hazard scientists are also becoming more aware of legal risks in our professions, and the combination of legal threats and scientific scorn might be enough to scare some into being very cautious (Bretton et al., 2015). It is not an easy balance to find.

Civil defense officials and politicians must find a similar balance. In their case, it is between taking adequate precautions without overly disrupting community life. Civil defense officials weigh the costs and logistical feasibility of risk reduction (evacuation, feeding costs, public impatience with community and business disruption) vs. the costs of not mitigating (principally, lives lost). Politicians will do the same, and also consider whether their actions improve or reduce their chances of reelection. Every decision about the timing or scale of evacuations requires officials to decide how much risk to accept. Officials rely on volcanologists to quantify the hazard, and on their political or social advisors to quantify what risks people are willing to take order to avoid disruptions of lives and livelihood. Although a few national standards of acceptable risk have been suggested (for example, Health and Safety Executive (UK), 2001), there is no widely accepted reference and most officials seem to base their decisions on semi-quantitative advice from volcanologists and on concerns from various stakeholders including residents and businesspeople.

Ideally, there might be a social contract between volcanologists, officials, and with citizens through their officials, that acknowledges uncertainties in eruption forecasts, discusses acceptable risk, and notes the possibility that one or more false alarms or missed alerts might occur as everyone strives to keep risk within acceptable limits. Where risk is to be quantified, scientists should ask decision-makers about what precision can be used, and whether there are key thresholds of risk that should be flagged. Community meetings help; social media, for all of their warts and noise, also offer some intriguing possibilities for getting the "pulse" of a community in the face of volcanic risk. Social scientists could play an important role by helping decision-makers judge acceptable risk.

\section{Effective Communication Between all Parties}

Effective communication between volcanologists, officials, traditional news media (not social media), and residents came into sharp focus after the Nevado del Ruiz disaster. There, much correct information had been sent, but not in forms that resonated with recipients. Volcanologists had provided traditional products like a 2-D hazard map and one-way briefings, but had not provided video or other more graphic depictions of the imminent hazard. There were also breakdowns in communication between neighboring political jurisdictions and, apparently, clergy had not been included. A summary of many cumulative communication failures may be found in 
Voight (1990), and Colombian scientists are now much more aware of communication issues than they or any others were previously (Calvache et al., 2021).

At Pinatubo, we faced several challenges in communication (Punongbayan et al., 1996; Newhall and Solidum, 2018). The first was time-everything we were doing, from installing monitoring stations to interpreting data and holding briefings and other outreach activities-was fighting against the clock. There were not enough hours in the day. Furthermore, our team was small and none of us was really trained or designated as a communicator. As mentioned earlier, Ray Punongbayan did an outstanding job, through a combination of scientific competence, ability to sketch and simplify, and personality. Others of us who were involved in communicating relied heavily on the rough cut of a video, Understanding Volcanic Hazards, made for the International Association of Volcanology and Chemistry of the Earth's Interior (IAVCEI) by the late Maurice and Katia Krafft after the disaster at Nevado del Ruiz. It illustrates each major volcanic hazard in graphic, even gruesome detail, and this video palpably helped us to convince skeptical audiences. This video was VERY helpful for those of us trying to explain such unfamiliar phenomena as pyroclastic flows, mudflows, ashfall, and the like. We showed and left copies of the Krafft video in nearly all of our briefings. Colleague Jack Lockwood and I also showed it to commanders of the US Pacific Forces in Hawaii, to get a green light for those at Clark AB to evacuate if needed.

In looking back, all of us at Pinatubo were doing everything we could to communicate, with everyone we met formally and informally. We briefed Aeta groups, political leaders from village to national levels, science teachers, Philippine and American military officials, and, informally, even a squad of the guerrilla New People's Army then operating on Pinatubo. It was just barely enough, again evidenced by skepticism right to up to the eruption. We were not expert communicators. But in the end, our communications plus spectacular VEI 3 eruptions during clear weather on June 12 convinced most skeptics. What if we had a larger, well-trained communication team? We could have done better. We might have given better advice about wet ashfall and roof collapse. And what if Pinatubo had not produced a vanguard dome and VEI 3 eruptions but, rather, gone straight to the VEI 6? For sure, more Aetas would have died, as the evacuations were continuing right up through June 14 and early June 15 .

Successful communication can hinge on just a single, critical message, delivered at a single, critical moment. But more often, it is an accumulation of many messages to many parties, spread over time. Many of these needed to be tailored to the audiences-upland farmers, politicians, and military commanders speak different languages and have different concerns. In Figure 1, one node calls attention to the issue of communication, but in reality, it was not a single event but rather, a continuous process with many chances and degrees of success or failure. It is unlikely that any single miscommunication would derail the whole train, but many miscommunications could sure slow it down.
One miscommunication caused damage but, fortunately, no fatalities. Volcanologists anticipated that the eruption would be large, and also knew that large eruptions produce ash clouds that can blow thousands of kilometers downwind. Smaller eruptions from Galunggung Volcano (Indonesia) had done just that in 1982, causing engine failures in at least 2 jumbo jets, and similar eruptions from Redoubt Volcano (Alaska) had done the same in 1989-1990 (Casadevall, 1994; Guffanti et al., 2010). Evidence was mounting that even distal ash could be dangerous for jet aircraft. International concern about ash hazard to aviation was driving a symposium on the topic, advertised and scheduled for early July 1991 in Seattle. Manila air traffic control and airlines operating out of Manila were aware that Pinatubo might erupt, but perhaps not of how far the ash might be blown downwind. More than a dozen Notices to Airmen (NOTAMS) were issued from April 12 up through June 15, the last few indicating closure of airways near Manila, and of the Manila airport. Meteorologists with access to near-real-time geostationary satellite images also knew of the hazard, and some were tracking the ash as it moved west from Pinatubo. To my knowledge, no Significant Meteorological Informations (SIGMETs) were issued with stronger wording about distant hazard, and airline operators were unprepared for the ash they would encounter far downwind from the Philippines. In retrospect, this was a multi-party communication failure, with insufficient warnings of distal ash but also insufficient attention from operators to the front-page stories about Pinatubo. Clearly, communication to other Flight Information Regions (FIRs) in Southeast Asia, and to pilots in those regions, was inadequate, and over a dozen planes flying over Indochina were damaged by ash (Casadevall et al., 1996).

Since the time of Pinatubo, and especially in the past 2 decades, volcanologists have become much more aware of communication issues, and an excellent book by Fearnley et al. (2018) reflects this greater awareness and attention. Calvache et al. (2021) offer painful but valuable insights into the challenges of communication around Colombian volcanoes. Communication is a huge issue for which few volcanologists are well prepared. The sooner we bring in expert help, the fewer miscommunications will occur. These days, observatory teams are adding social media specialists, because of the potential for quick, one-way and even two-way communications with whole communities. The VHS and Beta videotape technology we used at Pinatubo is an ancient artefact compared to today's options! On the specific miscommunication about ash hazard to aviation, there is now a vastly improved system, with nine Volcanic Ash Advisory Centers around the world, organized through the International Civil Aviation Organization (ICAO) and operating 24/7, in full communication with volcano observatories, meteorologists, air traffic control, and operators.

\section{CONCLUDING REMARKS}

Much of the literature of counterfactuals imagines disasters much worse than actually occur-worse either by nature or by human failures. The eruption of Pinatubo in 1991 was big enough to be a major disaster, and indeed did cause great immediate and 
subsequent damage, but the outcome could have been even worse without good forecasts or if mitigation measures were not undertaken. In retrospect, the eruption itself could have been up to several times larger, with major loss of life, or smaller than expected, with minimal damage other than to volcanologists' credibility (and jobs!). Mitigation of effects from the 1991 eruption was largely successful, but along the "train tracks" toward that mitigation, many things could have derailed or sidetracked the train. A few were matters of Nature, such as stochastic influence on whether and how magma erupted, or external distractions, natural or human. Most, though, were matters of human response to the crisis, from matters of capability and trust, scientific interpretation, communication, and decisions made by civil defense and political officials. Many decisions were judgment calls, made under high uncertainty, and some required balance between reputational caution and taking personal professional risk in order to save others. When uncertainties are high, there is naturally a high chance of disproportionate response, either too small or too large, too soon or too late. It is a tribute to all involved at Pinatubo, especially to the late Raymundo Punongbayan, that the response

\section{REFERENCES}

Aiuppa, A., Tamburello, G., Di Napoli, R., Cardellini, C., Chiodini, G., Giudice, G., et al. (2013). First Observations of the Fumarolic Gas Output from a Restless Caldera: Implications for the Current Period of Unrest (2005-2013) at Campi Flegrei. Geochem. Geophys. Geosyst. 14, 4153-4169. doi:10.1002/ggge.20261

Bretton, R. J., Gottsmann, J., Aspinall, W. P., and Christie, R. (2015). Implications of Legal Scrutiny Processes (Including the L'Aquila Trial and Other Recent Court Cases) for Future Volcanic Risk Governance. J. Appl. Volcanology 4 (1), 1-24. doi:10.1186/s13617-015-0034-x

Casadevall, T. J. (Editor) (1994). "Volcanic Ash and Aviation Safety: Proceedings of the First International Symposium on Volcanic Ash and Aviation Safety,"US Geol. Surv. Bull., 2047, 450.

Casadevall, T. J., Delos Reyes, P. J., and Schneider, D. J. (1996). "The 1991 Pinatubo Eruptions and Their Effects on Aircraft Operations," in Fire and Mud: Eruptions and Lahars of Mount Pinatubo, Philippines. Editors C.G. Newhall and R.S. Punongbayan (Quezon City, PHIVOLCS and Seattle: Univ of Washington Press), 1071-1088.

Calvache, V., M. L., Mendez, F., R. A., Monsalve, B., M. L., Gomez, M., D. M., Cortés, J., G. P., Lopez, V., C. M., et al. (2021). "Raising Awareness of Populations Living under Volcanic Risk the Colombian Case," in Forecasting and Planning for Volcanic Hazards, Risks, and Disasters. Editor P. Papale (Amsterdam: Elsevier), 585-616.

Chiodini, G., Paonita, A., Aiuppa, A., Costa, A., Caliro, S., De Martino, P., et al. (2016). Magmas Near the Critical Degassing Pressure Drive Volcanic Unrest towards a Critical State. Nat. Commun. 7, 13712-13719. doi:10.1038/ ncomms 13712

Coulon, C. A., Hsieh, P. A., White, R., Lowenstern, J. B., and Ingebritsen, S. E. (2017). Causes of Distal Volcano-Tectonic Seismicity Inferred from Hydrothermal Modeling. J. Volcanology Geothermal Res. 345, 98-108. doi:10.1016/j.jvolgeores.2017.07.011

Daag, A. S., Tubianosa, B. S., Newhall, C. G., Tuñgol, N. M., Javier, D., Dolan, M. T., et al. (1996). "Monitoring Sulfur Dioxide Emission at Mount Pinatubo," in Fire and Mud: Eruptions and Lahars of Mount Pinatubo, Philippines. Editors C.G. Newhall and R.S. Punongbayan (Quezon City, PHIVOLCS and Seattle: Univ of Washington Press), 409-414.

Fearnley, C. J., Bird, D. K., Haynes, K., McGuire, W. J., and Jolly, G. (Editors) (2018). Observing the Volcano World: Volcano Crisis Communication (New York, United States: Cham:Springer Open). was as successful as it was. There were many opportunities along the way for the Pinatubo mitigation train to derail, or be slowed down. No one should be complacent or overly confident in a situation like Pinatubo. Only a steady hand and attention to potential failures can steer the train to successful mitigation. Even with this special care, external factors can send a mitigation effort hurtling off the tracks! The mitigation team did (nearly) everything right, AND Pinatubo behaved as expected.

\section{DATA AVAILABILITY STATEMENT}

The original contributions presented in the study are included in the article/Supplementary Materials, further inquiries can be directed to the corresponding author.

\section{AUTHOR CONTRIBUTIONS}

The author confirms being the sole contributor of this work and has approved it for publication.

Fischer, T. P., Morrissey, M. M., Calvache, V. M. L., Gomez, M. D., Torres, C. R., Stix, J., et al. (1994). Correlations between SO2 Flux and Long-Period Seismicity at Galeras Volcano. Nature 368 (6467), 135-137. doi:10.1038/368135a0

Gerlach, T. M., Westrich, H. R., and Symonds, R. B. (1996). "Preeruption Vapor in Magma of the Climactic Mount Pinatubo Eruption: Source of the Giant Stratospheric Sulfur Dioxide Cloud," in Fire and Mud: Eruptions and Lahars of Mount Pinatubo, Philippines. Editors C.G. Newhall and R.S. Punongbayan (Quezon City, PHIVOLCS and Seattle: Univ of Washington Press), 415-433.

Geshi, N., Kusumoto, S., and Gudmundsson, A. (2010). Geometric Difference between Non-feeder and Feeder Dikes. Geology 38 (3), 195-198. doi:10.1130/ g30350.1

Gottsmann, J., Folch, A., and Rymer, H. (2006). Unrest at Campi Flegrei: A Contribution to the Magmatic versus Hydrothermal Debate from Inverse and Finite Element Modeling. J. Geophys. Res. 111. doi:10.1029/ 2005JB003745

Guffanti, M., Casadevall, T. J., and Budding, K. E. (2010). “Encounters of Aircraft with Volcanic Ash Clouds: a Compilation of Known Incidents, 19532009,"US Geological Survey Data Series 545, ver. 1.0, 12 pp plus 4 appendices. Available at: http://pubs.usgs.gov/ds/545 (Accessed September 28, 2021)

Harlow, D. H., Power, J. A., Laguerta, E. P., Ambubuyog, G., White, R. A., and Hoblitt, R. P. (1996). "Precursory Seismicity and Forecasting of the June 15, 1991, Eruption of Mount Pinatubo," in Fire and Mud: Eruptions and Lahars of Mount Pinatubo, Philippines. Editors C.G. Newhall and R.S. Punongbayan (Quezon City, PHIVOLCS and Seattle: Univ of Washington Press), 285-305.

Health and Safety Executive (UK) (2001). Reducing Risks; Protecting People. HSE's Decision Making Process. Available at: http://www.hse.gov.uk/risk/theory/r2p2. pdf (Accessed June 23, 2021).

Kilburn, C. R. J. (2018). Forecasting Volcanic Eruptions: Beyond the Failure Forecast Method. Front. Earth Sci. 6 (133), 15. doi:10.3389/feart.2018.00133

Leone, F., and Gaillard, J.-C. (1999). Analysis of the Institutional and Social Responses to the Eruption and the Lahars of Mount Pinatubo Volcano from 1991 to 1998 (Central Luzon, Philippines). GeoJournal 49, 223-238. doi:10.1023/a:1007076704752

McCausland, W. A., Gunawan, H., White, R. A., Indrastuti, N., Patria, C., Suparman, Y., et al. (2019). Using a Process-Based Model of Pre-eruptive Seismic Patterns to Forecast Evolving Eruptive Styles at Sinabung Volcano, Indonesia. J. Volcanology Geothermal Res. 382, 253-266. doi:10.1016/ j.jvolgeores.2017.04.004 
Moran, S. C., Newhall, C., and Roman, D. C. (2011). Failed Magmatic Eruptions: Late-Stage Cessation of Magma Ascent. Bull. Volcanol 73 (2), 115-122. doi:10.1007/s00445-010-0444-X

Mori, J., White, R. A., Harlow, D. H., Okubo, P., Power, J. A., Hoblitt, R. P., et al. (1996). "Volcanic Earthquakes Following the 1991 Climactic Eruption of Mount Pinatubo: Strong Seismicity during a Waning Eruption," in Fire and Mud: Eruptions and Lahars of Mount Pinatubo, Philippines. Editors C.G. Newhall and R.S. Punongbayan (Quezon City, PHIVOLCS and Seattle: Univ of Washington Press), 339-350.

Newhall, C. G., Daag, A. S., Delfin, F. G., Jr., Hoblitt, R. P., McGeehin, J., Pallister, J., et al. (1996). "Eruptive History of Mount Pinatubo," in Fire and Mud: Eruptions and Lahars of Mount Pinatubo, Philippines. Editors C.G. Newhall and R.S. Punongbayan (Quezon City, PHIVOLCS and Seattle: Univ of Washington Press), 165-195.

Newhall, C. G., Pallister, J. S., and Miller, C. D. (2021). “A Checklist for Crisis Operations within Volcano Observatories," in "in Forecasting and Planning for Volcanic Hazards, Risks, and Disasters. Editor P. Papale (Amsterdam: Elsevier), 493-544. doi:10.1016/b978-0-12-818082-2.00013-5

Newhall, C. G., and Punongbayan, R. S. (Editors) (1996a). Fire and Mud: Eruptions and Lahars of Mount Pinatubo, Philippines Quezon City, PHIVOLCS and Seattle: Univ of Washington Press.

Newhall, C. G., and Punongbayan, R. S. (1996b). "The Narrow Margin of Successful Volcanic-Risk Mitigation," in Monitoring and Mitigation of Volcano Hazards" in Monitoring and Mitigation of Volcanic Hazards. Editors R. Scarpa and R. I. Tilling (Berlin: Springer), 807-838. doi:10.1007/ 978-3-642-80087-0_25

Newhall, C., and Solidum, R. U. (2017). "Volcanic Hazard Communication at Pinatubo from 1991 to 2015," in Observing the Volcano World: Volcano Crisis Communication. Editors C.J. Fearnley, B. McGuire, G. Jolly, D. Bird, and K. Haynes (New York, United States: Cham:Springer Open), 189-203. doi:10.1007/11157_2016_43

Poland, M. (2010). Learning to Recognize Volcanic Non-eruptions. Geology 38 (3), 287-288. doi:10.1130/focus032010.1

Poland, M. P., and Anderson, K. R. (2020). Partly Cloudy with a Chance of Lava Flows: Forecasting Volcanic Eruptions in the Twenty-first century. J. Geophys. Res. Solid Earth 125 (1), e2018JB016974. doi:10.1029/2018jb016974

Punongbayan, R. S., Bautista, M. L. P., Harlow, D. H., Newhall, C. G., and Hoblitt, R. P. (1996). "'Pre-eruption hazard Assessments and Warnings," in Fire and
Mud: Eruptions and Lahars of Mount Pinatubo, Philippines. Editors C. G. Newhall and R. S. Punongbayan (Quezon City, PHIVOLCS and Seattle: Univ of Washington Press), 67-85.

Stix, J., Zapata, G., J. A., Calvache, V., M. L., Cortes, J., G. P., Fischer, T. P., Gomez, M., D., et al. (1993). A Model of Degassing at Galeras Volcano, Colombia, 19881993. Geol 21 (11), 963-967. doi:10.1130/0091-7613(1993)021<0963. amodag $>2.3 . \mathrm{co} ; 2$

Symonds, R. B., Gerlach, T. M., and Reed, M. H. (2001). Magmatic Gas Scrubbing: Implications for Volcano Monitoring. J. Volcanology Geothermal Res. 108 (1-4), 303-341. doi:10.1016/s0377-0273(00)00292-4

Troise, C., De Natale, G., Schiavone, R., Somma, R., and Moretti, R. (2019). The Campi Flegrei Caldera Unrest: Discriminating Magma Intrusions from Hydrothermal Effects and Implications for Possible Evolution. Earth-Science Rev. 188, 108-122. doi:10.1016/j.earscirev.2018.11.007

Voight, B. (1990). The 1985 Nevado del Ruiz volcano catastrophe: anatomy and retrospection. J. Volcanology Geothermal Res. 42, 151-188. doi:10.1016/03770273(90)90075-q

White, R., and McCausland, W. (2016). Volcano-tectonic Earthquakes: A New Tool for Estimating Intrusive Volumes and Forecasting Eruptions. J. Volcanology Geothermal Res. 309, 139-155. doi:10.1016/ j.jvolgeores.2015.10.020

Conflict of Interest: The author declares that the research was conducted in the absence of any commercial or financial relationships that could be construed as a potential conflict of interest.

Publisher's Note: All claims expressed in this article are solely those of the authors and do not necessarily represent those of their affiliated organizations, or those of the publisher, the editors and the reviewers. Any product that may be evaluated in this article, or claim that may be made by its manufacturer, is not guaranteed or endorsed by the publisher.

Copyright $(92021$ Newhall. This is an open-access article distributed under the terms of the Creative Commons Attribution License (CC BY). The use, distribution or reproduction in other forums is permitted, provided the original author(s) and the copyright owner(s) are credited and that the original publication in this journal is cited, in accordance with accepted academic practice. No use, distribution or reproduction is permitted which does not comply with these terms. 